\title{
Benthos supported by the tunnel-valleys of the southern North Sea
}

\author{
Bryony Pearce ${ }^{1^{\star}}$, David, R.Tappin ${ }^{2}$, Dayton Dove $^{3} \&$ Jennifer Pinnion ${ }^{1}$ \\ 1. Marine Ecological Surveys Limited, 3 Palace Yard Mews, Bath BA1 2NH \\ 2. British Geological Survey, Keyworth, Nottingham \\ 3. British Geological Survey, Edinburgh \\ * Corresponding Author; Email: bryony@seasurvey.co.uk, Telephone: +44(0) 1225 442211, Fax: +44 (0) 1225444411
}

\begin{abstract}
The tunnel-valleys of the southern North Sea are arcuate sub-linear seabed depressions. The origin of these features has been the subject of much discussion, but they are generally considered to have been formed by subglacial erosion and sediment backfill beneath the outer margins of a receding ice sheet. We present here a study of two southern North Sea tunnel-valleys, the Silver and Sole Pits. Extensive areas of Sabellaria spinulosa reefs have been identified on the western flanks of the Silver Pit which extend down to the valley floor. It is likely that this reef complex would qualify as an Annex I habitat. The seabed of the Sole Pit is characterised by much sandier deposits than that of the Silver Pit, and supports an abundant bivalve community, dominated by Abra alba. This bivalve assemblage also contained Coarcuta obliquata which has only been recorded once before in the UK.
\end{abstract}

\section{Key Words}

Tunnel Valley, Benthos, Habitat, Seabed Mapping, Sabellaria spinulosa, Annex I Habitat, North Sea, Mulitbeam

\section{Introduction}

Tunnel-valleys are prominent features of the southern North Sea, where they form arcuate sub-linear seabed depressions with a limited sediment infill (Fig. 1). In the outer Humber area the valleys attain water depths up to $100 \mathrm{~m}$ and radiate outward from the mapped palaeo-ice margin of the Devensian (Weischelian) glaciations. The orientation of the valleys indicates that their origin is associated with the ice sheet although the precise process of formation is uncertain. It is likely that the valleys were formed either by sub-glacial fluvial activity or ice-damn breakouts (Jakulhaups).

Recent research in the southern North Sea has focused on buried equivalents of the Weischelian features that are located farther north and are of Elsterian age. These studies indicate that such valleys are the result of steady-state sub-glacial fluvial erosion and subsequent sediment backfill beneath the outer tens of kilometres of a northward receding ice sheet margin (Huuse et al., 2000; Praeg, 2003). The absence of sediment infill in the Southern North Sea tunnel valleys is not well understood, but may be due to either erosion during post-glacial sea-level rise, or an original lack of infill. Modern tidal forces are certainly of sufficient amplitude to prohibit future sediment deposition (Pingree and Griffiths, 1979; Proctor et al., 2001).

A detailed study of two of these tunnel valleys, the Silver Pit and the Sole Pit was carried out as part of a regional characterisation project funded through the Marine Aggregate Levy Sustainability Fund (Tappin et al., 2011). Comprehensive geophysical data were collected over sections of the Silver Pit and Sole Pit and subsequently ground truthed with biological samples in order to investigate the ecological assemblages associated with these seabed features. The benthic macrofauna were compared with fauna identified across the wider 
region as a means of assessing the ecological significance and surrogacy potential of the tunnel-valleys.

Geomorphic Features \& Habitats NB Include video fly-thru's for this section in on-line version

\section{The Silver Pit}

The Silver Pit is the larger of the two surveyed valleys. It is approximately $50 \mathrm{~km}$ long and up to $5 \mathrm{~km}$ wide with maximum water depths reaching almost $100 \mathrm{~m}$ (Fig. 2). The detailed survey area is located in the centre of the valley with an approximate dimension of $3.5 \mathrm{~km} \mathrm{x}$ $2 \mathrm{~km}$. It incorporates the shallow, relatively flat seabed, through which the valleys were cut, the valley flanks, and the valley floor. Within the detailed survey area the valley attains a maximum depth of approximately $90 \mathrm{~m}$. Typically the valley floor is gently undulating.

Within the valley three Quaternary formations are exposed at the seafloor where they subcrop the thin Holocene sediment cover. These formations (and their lithologies) are: in ascending order, Sand Hole (laminated clay), Egmond Ground (muddy sand) and Bolders Bank (boulder clay). On the valley floor there is a thin Holocene sediment cover that overlies Cretaceous Chalk.

The western flank of the valley is relatively uniform with a slope failure in the south-west corner. The displaced sediment rests on the valley floor (Fig 2). The eastern flank is more complex, and the otherwise continuous slope is interrupted by a terrace. These terraces are most likely the result of multiple phases of sub-glacial erosion. The seabed on top of this terrace is irregular with localized bathymetric highs formed of coarse material which either represents exposed Quaternary sediment or glacial lag deposits. Where sands predominate on the terrace, mega-ripples are also common.

Mega-ripples are also common in the western valley floor where finer sands occur. There are three small, rounded bathymetric highs of uncertain origin. They may be glacial relicts or simply localised areas where the Chalk is more resistant to erosion. Along the middle of the valley there are a series of linear bathymetric highs that generally parallel the orientation of the valley. These are probably glacial relicts that formed as moraines, and are also associated with exposures of coarser-grained sediments.

\section{Sole Pit}

The Sole Pit is approximately $30 \mathrm{~km}$ long and up to $3 \mathrm{~km}$ in width. The survey area has the approximate dimension $3.5 \mathrm{~km} \times 1.5 \mathrm{~km}$, incorporating the shallow, relatively flat surrounding seabed through which the valley was cut, the slopes (flanks) of the valley, and the valley floor, which has a maximum depth of approximately $90 \mathrm{~m}$ (Fig. 3).

The valley incises four Quaternary formations which underlie thin or absent Holocene sediments on the flanks. In ascending order these formations (and their lithologies) are: Winterton Shoal (interbedded sand and clay), Yarmouth Roads (Sand interbedded with silty clay), Bolders Bank (boulder clay) and Botney Cut (laminated clay). Where Holocene sediments are present on the valley floor these are thin and are underlain by the Botney Cut formation in the northeast of the valley, and by Triassic and Jurassic Lias Group formations in the west and south. The Lias Group comprises both sandstone and limestone.

Both valley flanks have continuous and undisturbed slopes, although in the east there are small areas of mega-ripples (Fig. 3). The morphology of the valley floor in the west and south is characterised by the curvilinear strike of the underlying rock. Individual lineations 
appear to be associated with occurrences of smaller hummocky features that typically constitute coarser sediments than the surrounding area. It is unclear whether these hummocky features are outcrops of rock or glacial deposits that may have nucleated along the bedding planes of the underlying rock.

In the extreme south east there is a large sand wave feature upon which there are smaller parasitic mega-ripples. The profile of the sand wave, and the smaller sand waves in the north indicate predominantly north trending bottom currents. In the east of the valley floor there are two longitudinal deeps that indicate localized glacial erosion.

\section{Biological Communities}

The biological communities of the outer Humber study area were characterised by analysing 135 mini Hamon grab $\left(0.1 \mathrm{~m}^{2}\right)$ samples including ten from the focused study area in the Silver Pit and a further six from the focused study area in the Sole Pit. Macrofauna $(>1 \mathrm{~mm})$ were extracted from the grab samples and identified to the highest possible taxonomic resolution, usually to species level, and counted. The quantitative faunal data recorded from these samples was supplemented with observations from seabed video and digital stills acquired at the same stations. Sub-samples were taken from each of the grab samples and analysed to give full particle size distribution based on the Wentworth scale. The nature of the substrate was also recorded from seabed images and video footage.

Benthic species abundance data recorded from the detailed survey areas were used to characterise the biological communities associated with the Silver Pit and the Sole Pit using the SIMPER routine in the PRIMER (V6) software. The ANOSIM test was used to investigate differences between the macrofauna associated the tunnel-valleys and macrofauna recorded across the wider Humber study area. Finally, the Bio-Env routine was used to investigate the surrogacy potential of these geomorphic features using environmental data summarised in Table 1.

\section{The Silver Pit}

The Silver Pit can be split into three broad morphological categories, the western slope, the tunnel floor and the eastern slope. Beyond the valley itself the margin sediments are typically sandy gravels, although there is a larger mud component on the eastern margins. The sandy gravel deposits extend down the slopes of the valley becoming increasingly sandy towards the base of the slope. The floor of the tunnel valley is predominantly gravelly sand although there are occurrences of slightly gravelly sand in the west of the valley floor as well as muddy sandy gravel associated with the linear glacial relicts in the middle of the valley floor.

\section{The Western Slope}

The biological communities associated with the western slopes of the Silver Pit are numerically dominated by the Ross worm Sabellaria spinulosa. An irregular, textured signature was visible in much of the side-scan sonar data collected across this area (Fig. 4i) which has been reported to be indicative of the biogenic reefs built by this polychaete (MESL, 2009, MESL, 2006 and MESL, 2005). The presence of this textured signature across the slope suggests that this area may support an extensive reef complex which is likely to qualify as an Annex I habitat under the EC Habitats Directive (Council Directive 92/43/EEC on the conservation of natural habitats and of wild fauna and flora). The majority of seabed images collected from the western slopes of the Silver Pit also show significant $S$. spinulosa concretions (Fig. 4i) typically in association with the pink shrimp Pandalus monatgui, the erect bryozoan, Flustra foliacea and the edible mussel Mytilus edulis. In some 
areas the seafloor was found to be covered by $S$. spinulosa reef and $M$. edulis in equal volumes indicating a mixed reef assemblage which has not previously been reported in the literature.

\section{The Valley Floor}

The valley floor was also found to support Sabellaria spinulosa aggregations although the densities recorded from the grab samples were significantly lower than those recorded on the western slopes. Examination of the seabed video and still images reveals a less topographically distinct 'carpet' reef (Fig. 4ii), indicating that tube growth is being limited, possibly by the fast water currents running through the valley. The carpet reef identified across the floor of the tunnel valley is also inhabited by brittle stars which were conspicuous in the seabed imagery (Fig. 4ii). The nature of the association between S. spinulosa and the brittle stars is not clear but given that both species are filter feeders there is potential for the brittle stars to limit the food available to the sedentary polychaetes if they reach high enough densities.

\section{The Eastern Slope}

Sabellaria spinulosa reefs are notably absent from the eastern slopes of the Inner Silver Pit, with sporadic records of only a few individuals. The absence of significant aggregations indicates that the environmental conditions of the eastern slopes are less suited to this species than in the rest of the valley and it is likely that this is in some part influenced by the sediment composition. Sabellariid polychaetes are dependent on a good supply of sand which they use to construct their tubes (Chen \& Dai, 2009, Kirtley, 1994 and Pohler, 2004). The eastern flanks are known to be muddier than the rest of the tunnel valley and this alone may make the area unsuitable for the development of $S$. spinulosa reefs. Significant amounts of fine sediments may also foul the ciliary feeding apparatus of the worm, as has been reported for the congener Sabellaria kaiparensis (Wells, 1970).

Despite the absence of $S$. spinulosa reefs the eastern slopes support a comparatively diverse and numerically abundant faunal assemblage (Table 2). There is an abundance of epifauna here including hydroid turfs and sea squirts (Fig. 4iii), and an abundant infaunal community including the bamboo worm Euclymene and the amphipod Urothoe elegans.

\section{The Sole Pit}

The sediments of the Sole Pit are sandier than those of the Silver Pit with the margins and upper slopes being comprised of gravelly sands and the lower slopes and valley floor being comprised of slightly gravelly muddy sands. The biological communities associated with this tunnel valley feature are also markedly different from those associated with the Inner Silver Pit (Fig. 4iv), although it should be noted that only six samples were taken from this feature and all were located in the valley floor. The most abundant species recorded from the Sole Pit was the bivalve mollusc, Abra alba with over 4000 individuals recorded from six grab samples. Other abundant fauna included the brittle star Amphiura filiformis and the tiny poychaete Anobothrus gracilis. 


\section{Surrogacy}

In order to investigate the relationship between the tunnel-valleys and the benthos across the Outer Humber study area, the biological composition of samples collected from within valley features were compared with the biological composition recorded across the wider area (Fig. 1). An ANOSIM test found no significant difference between the faunal communities within the valleys and those found in the wider environs $(R=0.034,19.1 \%$ Sig). However, this is likely to be influenced in part by the wide variety of habitats and faunal communities found across the Outer Humber Region (Tappin et al., 2011).

A number of species were found to be entirely unique to the tunnel-valleys (Table 3 ) the most notable being the small bivalve mollusc, Coracuta obliquata which has only been recorded once in UK waters over the last 100 years (Holmes, et al., 2006). This bivalve appears to have very specific environmental requirements, having been recorded in five of the six samples taken from the floor of the Sole Pit. Holmes et al., (2006) observed C. obliquata in sediments ranging from sand to sandy gravel which corresponds well with our observations in the Sole Pit where this mollusc was observed in gravelly sand. A Bio-Env analysis on C. obliquata yielded a maximum correlation of 0.341 with Geomorphic Feature (Table 4a). This reflects the localised distribution of this species within the Sole Pit although this alone could not be used as a surrogate for the distribution of $C$. obliquata. The distribution of this species is likely to be determined by a combination of environmental factors, including some not recorded as part of this study, and also by biological interactions. Other species in the same family of molluscs (Montacutidae) are known to have commensal relationships with other invertebrates (Josefson, 1998; Morton and Scott 1969; Tebble, 1966). It is possible that the same is true of $C$. obliquata although no specific associations have as yet been identified.

The Sabellaria spinulosa reef complex found in association with the Silver Pit has previously been noted in environmental impact assessments of adjacent aggregate extraction areas (Emu, 2005, MES, 2003, MES, 2009) indicating that it is a relatively persistent feature of the sea bed. An area of S. spinulosa reef to the south of the Silver Pit has been included as a conservation feature in the Inner Dowsing, Race Bank and North Ridge possible Special Area of Conservation (pSAC) which is currently being assessed for inclusion into the Natura 2000 network (JNCC, 2010). The areas of reef identified in the focused study of Silver Pit fall out of the proposed pSAC boundary but it is possible that this may be incorporated into the area protected on the basis of the evidence presented here.

A Bio-Env analysis carried out on the Outer Humber Region revealed that various aspects of the hydrodynamic regime and sediment composition gave the best correlations with $S$. spinulosa abundance in this area (Table 4b). However, given that the highest correlation identified was 0.341 , these factors alone could not be used as a surrogate of $S$. spinulosa distribution.

The tunnel-valleys of the southern North Sea have not been found to be effective surrogates for any benthic species or assemblages. However, these features support a variety of marine life, including species and habitats which may be of conservation interest. The physical attributes of the tunnel-valleys makes them unsuitable for most anthropogenic activities which occur in the marine environment and hence it seems likely that these features will become an important component of the Natura 2000 network in years to come. 


\section{References}

Chen \& Dai, 2009. Subtidal sabellariid reefs in Hualien, eastern Taiwan. Coral Reefs. 28: 275.

Emu, 2005. "Area 480 Sabellaria spinulosa survey" Report prepared by Emu Environmental Ltd for Hanson Aggregates Marine Ltd, Southampton

Holmes, A.M., Gallichani, J. and Wood, H. 2006. Coracuta obliquata N.Gen (Chaster, 1897) (Bivalvia: Monacutidae) - First British Record for 100 years. Journal of Conchology, 39(2): 151-157.

Huuse, M., Lykke-Andersen, 2000. Overdeepened Quaternary valleys in the eastern Danish North Sea: morphology and origin. Quaternary Science Reviews, 19: 1233-1253.

JNCC, 2010. "Inner Dowsing, Race Bank and North Ridge Selection Assessment Document Version 5.0." Report prepared by the Joint Nature Conservation Committee (JNCC) and Natural England on behalf of the Department of Environment, Food and Rural Affairs (Defra). 34pp.

Josefson, A.B. 1998. Resource limitation in marine soft sediments - differential effects of food and space in the association between the brittle-star Amphiura filiformis and the bivalve Mysella bidentata? Hydrobiologia, 375/376: 297-305.

Kirtley, 1994. "A review and taxonomic revision of the family Sabellaridae (Annelida:Polychaeta)." Sabecon Press: Vero Beach, Florida, USA.

Morton, B. \& Scott, P.V. 1989. The Hong Kong Galeommatacea (Mollusca: Bivalvia) and their hosts, with descriptions of new species. Asian Marine Biology, 6: 129-160.

MESL, 2003. "Marine Aggregate Extraction Application Area 106 East (480): Environmental Statement". Report prepared by Marine Ecological Surveys Ltd (MESL) for Hanson Aggregates Marine Ltd, Southampton 199pp.

MESL, 2005. "Thanet Offshore Windfarm, Benthic and Intertidal Resource Survey". Report prepared by Marine Ecological Surveys Ltd for Haskoning UK Ltd. 86pp.

MESL, 2006. " Hastings Shingle Bank Area 366-370: Benthic Monitoring Report". Report Prepared by Marine Ecological Surveys Ltd (MESL) for the Resource Management Association (RMA). 86pp.

MESL, 2009. "Area 480: Benthic Biological Survey. Analysis of Survey Data for 2008 and Comparison with 2002 Survey Data". Report prepared by Marine Ecological Surveys Ltd (MESL) for Hanson Aggregates Marine Ltd, Southampton. 166pp.

Pingree, R.D. and Griffiths, D.K., 1979. Sand transport paths around the British Isles resulting from M2 and M4 tidal interactions. Journal of the Marine Biological Association, 59: 497-513.

Pohler, S.M.L. 2004. The Sabellariis worm colonies of Suva Lagoon, Fiji. South Pacific Journal of Natural History 22: 36-42.

Praeg, D., 2003. Seismic imaging of mid-Pleistocene tunnel-valleys in the North Sea Basin-high resolution from low frequencies. Journal of Applied Geophysics, 53(4): 273-298. 
Proctor, R., Holt, J.T. and Balson, P.S., 2001. Sediment deposition in offshore deeps of the western North Sea: Questions for models. Estuarine, Coastal and Shelf Science, 53: 553567.

Tappin, D., Pearce, B., Fitch, S., Dove, D., Hill, J., Ramsey, E., etc etc. 2011. Outer Humber Regional Environmental Characterisation. British Geological Survey Open Report OR/11/xx. XXXpp. Full reference will be available shortly

Tebble, N. 1966. "British bivalve seashells, a handbook for identification". British Museum (Natural History), London.

Wells, H.W. 1970. Sabellaria reef masses in Delaware Bay. Chesapeake Science 11: 258260. 


\section{Figures}

Figure 1. Single beam echosounder bathymetric map of the Humber Regional Environmental Characterisation (REC) study area based on a 25-250m grid. Stations sampled for biological analysis are also shown (those highlighted in red were taken from within the tunnel valley features). Shade source $315^{\circ}$ - NW. Single beam echo sounder data (c) British Crown \& Sea Zone Solutions Ltd. 2008. All rights reserved. Data License 052008.012.

Figure 2a. Bathymetric map of the Silver Pit focused study site and surrounding area. Stations sampled for biological analysis of the focused study site are also shown and the boundaries between the valley floor and slope edges are delineated by red dashed lines. Shade source $315^{\circ}$ - NW. Single beam echo sounder data (c) British Crown \& Sea Zone Solutions Ltd. 2008. All rights reserved. Data License 052008.012. NB fly-thru in web version. b. Depth profile of the Silver Pit.

Figure 3a. Bathymetric map of the Sole Pit focused study site and surrounding area. Stations sampled for biological analysis of the focused study site are also shown and the boundaries between the valley floor and slope edges are delineated by red dashed lines. Shade source $315^{\circ}$ - NW. Single beam echo sounder data (c) British Crown \& Sea Zone Solutions Ltd. 2008. All rights reserved. Data License 052008.012. NB fly-thru in web version. b. Depth profile of the Sole Pit.

Figure 4. Typical sediment deposits, side-scan sonar signatures and fauna associated with Silver Pit and Sole Pit. i) Silver Pit - Western Slope A) Sabellaria spinulosa B) Flustra foliacea C) Pandalus montagui D) Mytilus edulis. ii) Silver Pit - Floor A) Sabellaria spinulosa B) Ophiura albida C) Ophiothrix fragilis D) Lumbrineris gracilis. iii) Silver Pit Eastern Slope A) ACSIDIACEA B) Sertularia cupressina C) Euclymene D) Urothoe elegans. iv) Sole Pit - Floor A) Abra alba B) Anobothrus gracilis C) Coracuta obliquata D) Amphiura filiformis. - NB Photograph of Coracuta is on its way 


\section{Tables}

Table 1. Summary of the environmental variables used to investigate potential surrogates for benthic macrofauna in Outer Humber region.

Table 2. The average number of species (S), number of individuals $(N)$, Shannon Weiner's Diversity $\left(\mathrm{H}^{\prime}\right)$ and Taxonomic Distinctness (Delta*) recorded in $0.1 \mathrm{~m}^{2}$ Hamon grab samples taken within and outside of the tunnel-valley features.

Table 3. Summary of species found to be unique to the Inner Silver Pit $(n=10)$, the Sole Pit $(n=5)$ and the wider study region in the Outer Humber $(n=110)$. Only species with an average abundance greater than 0.1 per grab are shown. The total number of unique taxa is given in brackets.

Table 4. Summary of Bio-Env analyses carried to investigate the environmental surrogates which best correlate with the distribution patterns of A) Coracuta obliquata and B) Sabellaria spinulosa in the Outer Humber region. 


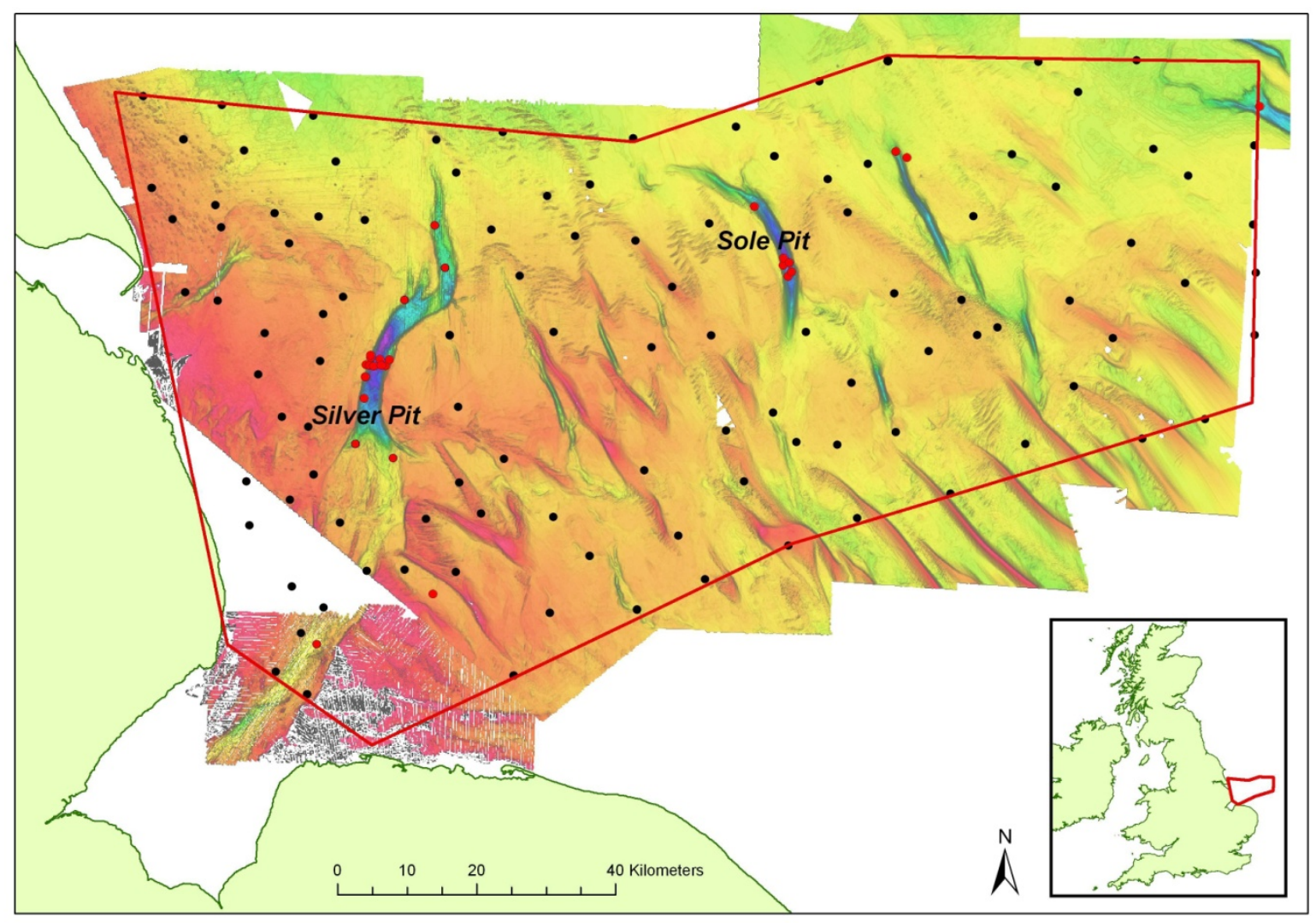

Figure 1. Single beam echosounder bathymetric map of the Humber Regional Environmental Characterisation (REC) study area based on a 25-250m grid. Stations sampled for biological analysis are also shown (those highlighted in red were taken from within the tunnel valley features). Shade source $315^{\circ}-$ NW. Single beam echo sounder data (C) British Crown \& Sea Zone Solutions Ltd. 2008. All rights reserved. Data License 052008.012. 

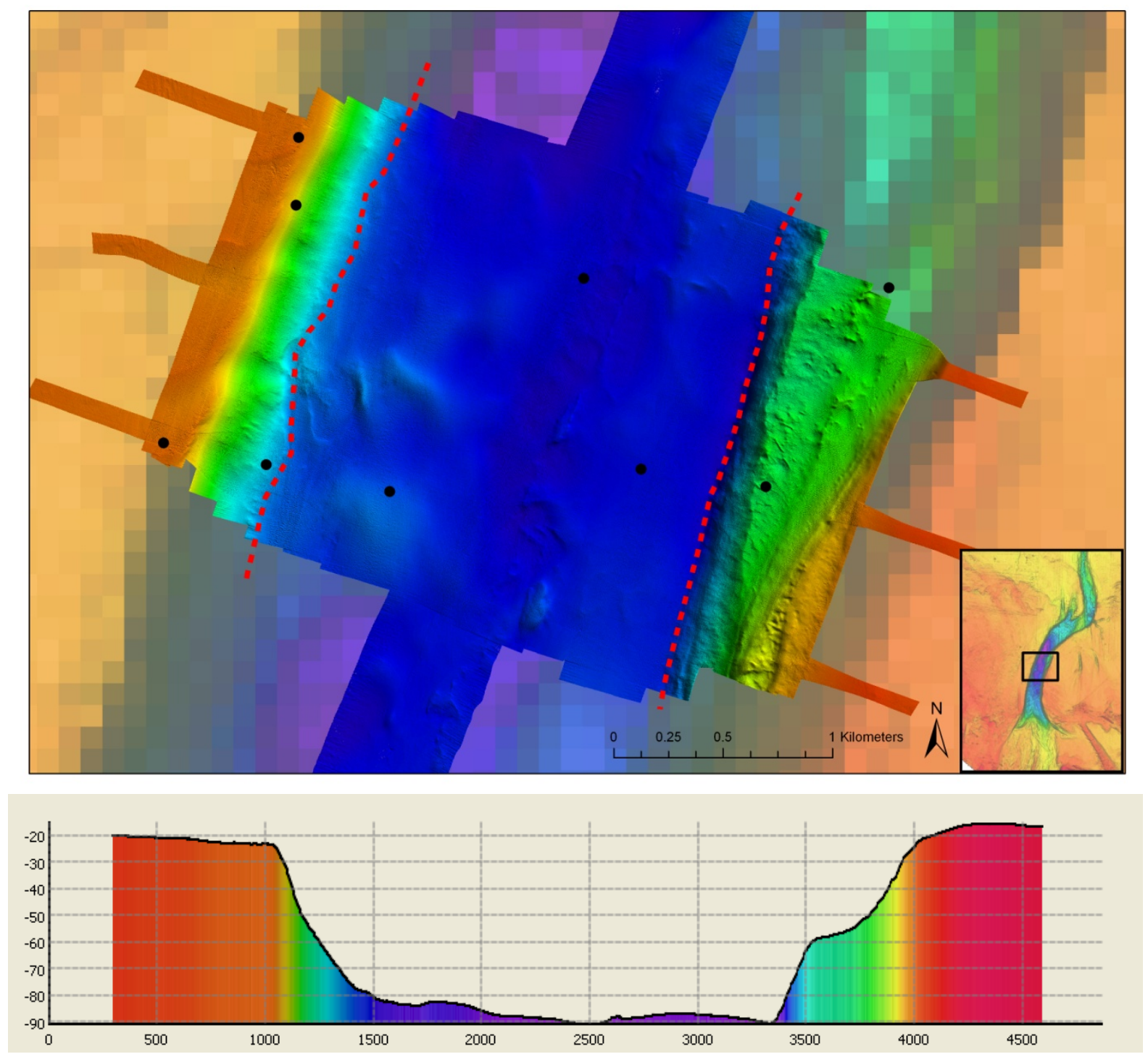

Figure 2a. Bathymetric map of the Silver Pit focused study site and surrounding area. Stations sampled for biological analysis of the focused study site are also shown and the boundaries between the valley floor and slope edges are delineated by red dashed lines. Shade source $315^{\circ}$ - NW. Single beam echo sounder data @ British Crown \& Sea Zone Solutions Ltd. 2008. All rights reserved. Data License 052008.012. NB fly-through in web version. b. Depth profile of the Silver Pit. 

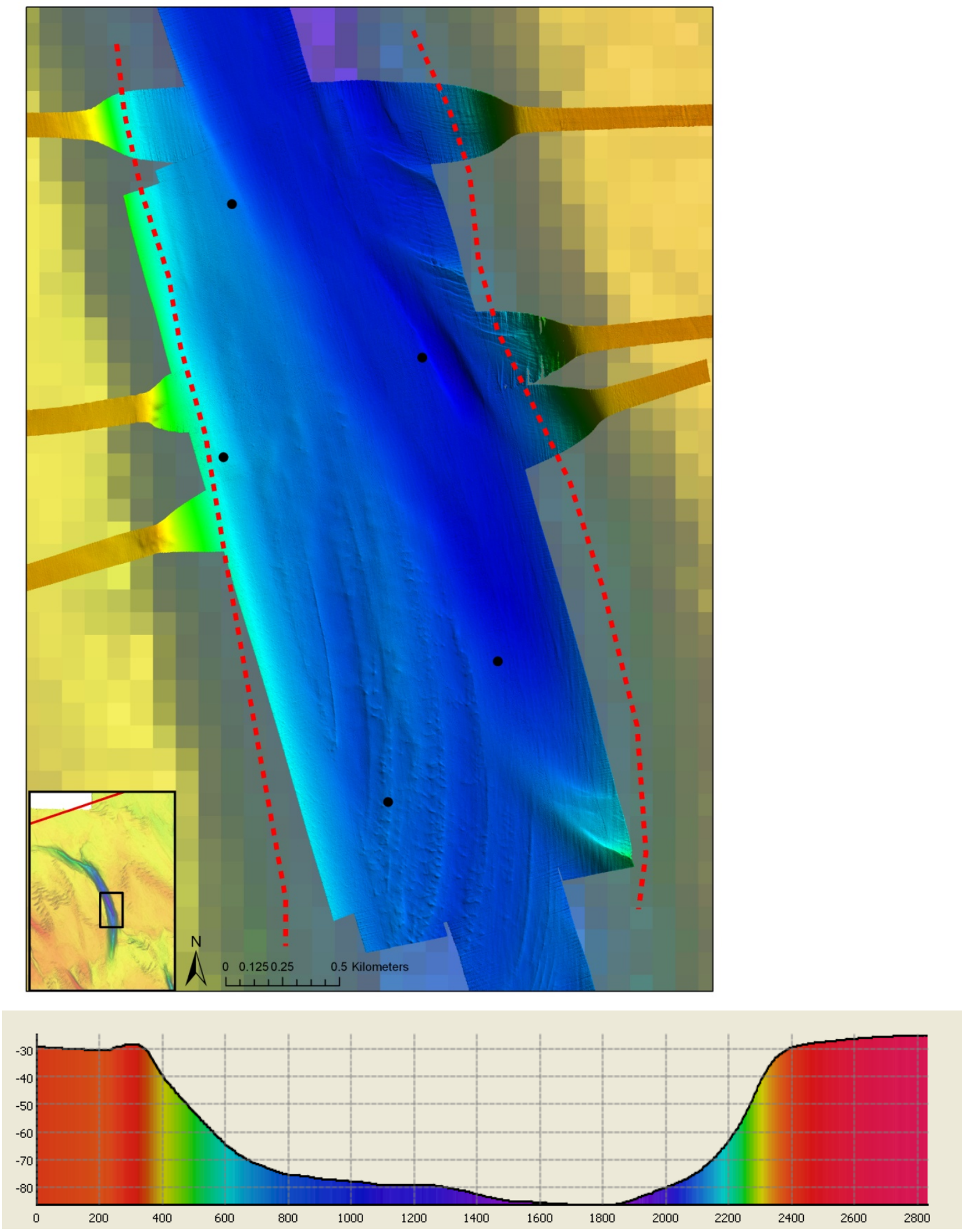

Figure 3a. Bathymetric map of the Sole Pit focused study site and surrounding area. Stations sampled for biological analysis of the focused study site are also shown and the boundaries between the valley floor and slope edges are delineated by red dashed lines. Shade source $315^{\circ}$ - NW. Single beam echo sounder data $\odot$ British Crown \& Sea Zone Solutions Ltd. 2008. All rights reserved. Data License 052008.012. NB fly-through in web version. b. Depth profile of the Sole Pit. 

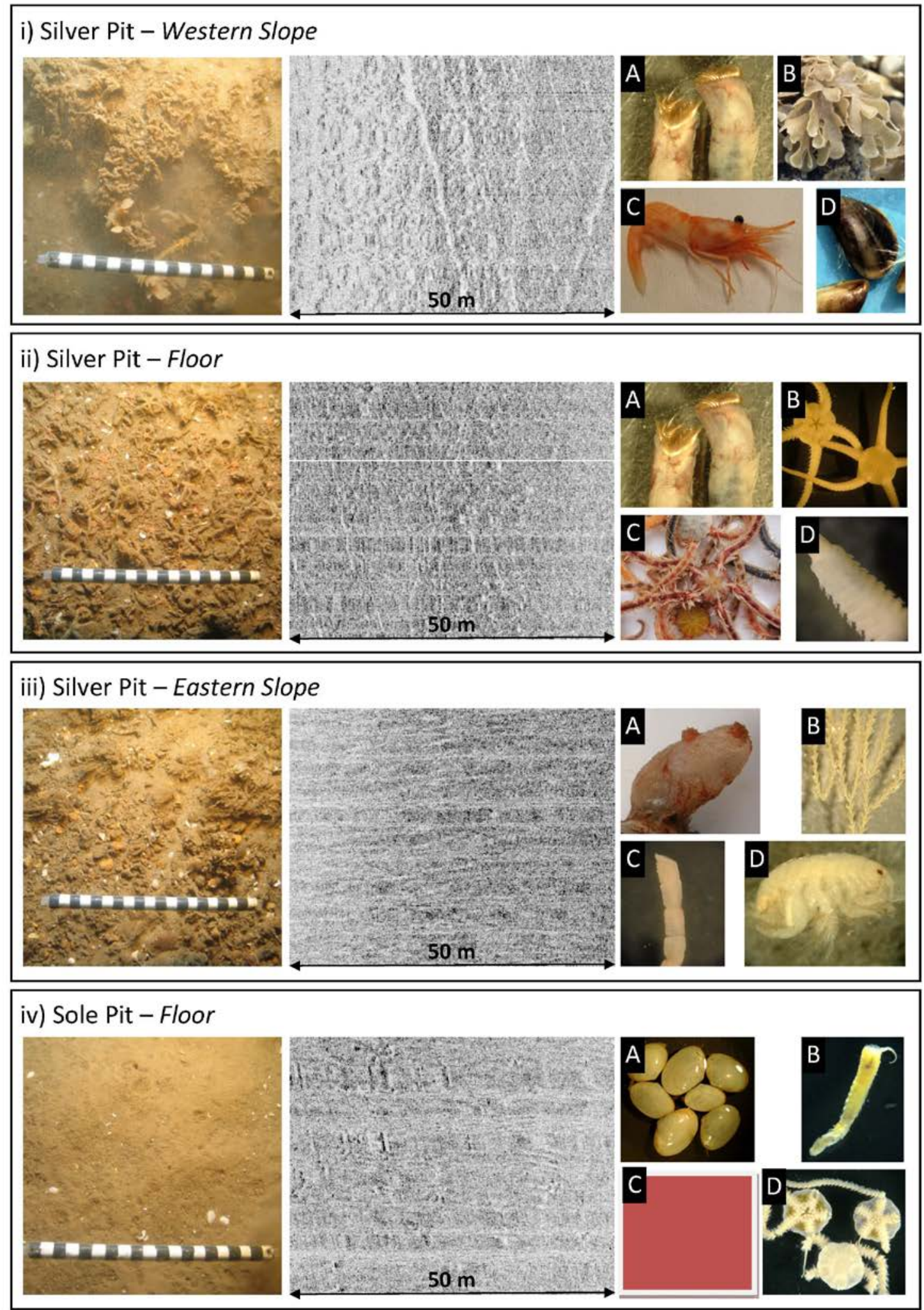

Figure 4. Typical sediment deposits, side-scan sonar signatures and fauna associated with Silver Pit and Sole Pit. i) Silver Pit - Western Slope A) Sabellaria spinulosa B) Flustra foliacea C) Pandalus montagui D) Mytilus edulis. ii) Silver Pit - Floor A) Sabellaria spinulosa B) Ophiura albida C) Ophiothrix fragilis D) Lumbrineris gracilis. iii) Silver Pit Eastern Slope A) ACSIDIACEA B) Sertularia cupressina C) Euclymene D) Urothoe elegans. iv) Sole Pit - Floor A) Abra alba B) Anobothrus gracilis C) Coracuta obliquata D) Amphiura filiformis. - NB Photograph of Coracuta is on its way 


\begin{tabular}{|c|c|c|}
\hline Variable & Data Type & Details \\
\hline Geomorphic Feature & Categorical & $\begin{array}{l}\text { As described in Figures 1-3; Sole Pit (Floor) }=5, \\
\text { Silver Pit (Eastern Slope) }=4 \text {, Silver Pit (Floor) }=3 \text {, } \\
\text { Silver Pit (Western Slope) }=2 \text {, Other tunnel-valleys } \\
=1 \text {, wider Humber area }=0\end{array}$ \\
\hline$\%$ Mud & Numerical & $\begin{array}{l}\text { \% of sample (by weight) recorded from the Hamon } \\
\text { grab samples. }\end{array}$ \\
\hline$\%$ Sand & Numerical & $\begin{array}{l}\% \text { of sample (by weight) recorded from the Hamon } \\
\text { grab samples. NB. } \% \text { Gravel was removed from } \\
\text { this analysis as there was a very strong correlation } \\
\text { with } \% \text { Sand. \% Sand should therefore be treated } \\
\text { as a proxy for } \% \text { Gravel. }\end{array}$ \\
\hline Sorting & Numerical & $\begin{array}{l}\text { Sorting-(standard deviation) of the grain sizes (phi) } \\
\text { recorded from Hamon grab samples (Folk \& Ward, } \\
\text { 1957) }\end{array}$ \\
\hline Skewness & Numerical & $\begin{array}{l}\text { Skewness (asymmetry) of the sediment } \\
\text { composition (phi) recorded from Hamon grab } \\
\text { samples (Folk \& Ward, 1957) }\end{array}$ \\
\hline Kurtosis & Numerical & $\begin{array}{l}\text { Kutosis (peakedness) of the sediment composition } \\
\text { (phi) recorded from Hamon grab samples (Folk \& } \\
\text { Ward, 1957) }\end{array}$ \\
\hline Wave Strength & Modelled Numerical & $\begin{array}{l}\text { Annual mean wave power }(\mathrm{kW} / \mathrm{m}) \text { per horizontal } \\
\text { metre of wave crest calculated using the energy } \\
\text { period calculation (TE) @ C Crown Copyright. All } \\
\text { rights reserved } 2008 \text {. }\end{array}$ \\
\hline $\begin{array}{l}\text { Tidal Current } \\
\text { Velocity }\end{array}$ & Modelled Numerical & $\begin{array}{l}\text { Maximum amplitude of the depth averaged mean } \\
\text { spring tidal current }(\mathrm{m} / \mathrm{s})\end{array}$ \\
\hline $\begin{array}{l}\text { Near Bed } \\
\text { Temperature }\end{array}$ & Modelled Numerical & $\begin{array}{l}\text { Month averaged near bed temperature, resolution } \\
1 / 9 \text { degrees calculated using the Atlantic Margin } \\
\text { Model (www.myocean.eu.org) }\end{array}$ \\
\hline Seafloor Rugosity & Modelled Numerical & $\begin{array}{l}\text { Rugsity (ratio of surface area to planar area) of the } \\
\text { seafloor calculated from single beam echosounder } \\
\text { bathymetric data on a 25-250m grid using the } \\
\text { Benthic Terrain Model (BTM) in ArcGIS V9.3. ( } \\
\text { British Crown \& Sea Zone Solutions Ltd. 2008. All } \\
\text { rights reserved. Data License 052008.012. }\end{array}$ \\
\hline Slope & Modelled Numerical & $\begin{array}{l}\text { Slope (degrees) calculated using Spatial Analyst in } \\
\text { ArcGIS V9.3 from single beam echosounder } \\
\text { bathymetric data on a } 25-250 \mathrm{~m} \text { grid } \odot \text { British } \\
\text { Crown \& Sea Zone Solutions Ltd. } 2008 \text {. All rights } \\
\text { reserved. Data License } 052008.012 \text {. }\end{array}$ \\
\hline
\end{tabular}

Table 1. Summary of the environmental variables used to investigate potential surrogates for benthic macrofauna in Outer Humber region. 


\begin{tabular}{lcccc}
\hline & $\mathrm{S}$ & $\mathrm{N}$ & H'(Loge) $^{\prime}$ & Delta* \\
\hline \hline Silver Pit - Western Slope $(\mathrm{n}=5)$ & 171 & 517 & 2.55 & 90.55 \\
Silver Pit - Floor $(\mathrm{n}=3)$ & 118 & 478 & 2.97 & 86.72 \\
Silver Pit - Eastern Slope $(\mathrm{n}=2)$ & 149 & 405 & 3.88 & 93.62 \\
Sole Pit - Floor $(\mathrm{n}=6)$ & 164 & 1125 & 1.74 & 93.80 \\
& & & & \\
\hline All Tunnel Valley Stations (n=25) & 425 & 661 & 3.34 & 91.81 \\
None Tunnel Valley Stations (n=110) & 636 & 317 & 3.83 & 90.61 \\
\hline
\end{tabular}

Table 2. The average number of species $(S)$, number of individuals $(N)$, Shannon Weiner's Diversity $\left(\mathrm{H}^{\prime}\right)$ and Taxonomic Distinctness (Delta*) recorded in $0.1 \mathrm{~m}^{2}$ Hamon grab samples taken within and outside of the tunnel-valley features. 


\begin{tabular}{|c|c|c|c|c|c|}
\hline \multicolumn{2}{|c|}{ Outer Humber Region (259) } & \multicolumn{2}{|l|}{ Silver Pit (33) } & \multicolumn{2}{|l|}{ Sole Pit (12) } \\
\hline Species & $\bar{n}$ & Species & $\bar{n}$ & Species & $\bar{n}$ \\
\hline Bathyporeia elegans & 1.59 & Ophiactis balli & 0.47 & Coracuta obliquata & 3.33 \\
\hline Nymphon brevirostre & 1.52 & Socarnes erythrophthalmus & 0.13 & Malmgreniella andreapolis & 1.33 \\
\hline Alvania semistriata & 0.34 & Vitreolina philippi & 0.13 & Hyala vitrea & 0.67 \\
\hline Fabulina fabula & 0.27 & & & Retusa umbilicata & 0.50 \\
\hline Monocorophium acherusicum & 0.25 & & & Echiurus echiurus & 0.17 \\
\hline Pomatoceros triqueter & 0.21 & & & Myriochele danielsseni & 0.17 \\
\hline Aonides oxycephala & 0.19 & & & Ebalia nux & 0.17 \\
\hline Polydora cornuta & 0.18 & & & Palio dubia & 0.17 \\
\hline Alcyonidium mytili & 0.18 & & & Devonia perrieri & 0.17 \\
\hline Glycera oxycephala & 0.17 & & & Saxicavella jeffreysi & 0.17 \\
\hline Urothoe poseidonis & 0.17 & & & & \\
\hline Branchiostoma lanceolatum & 0.16 & & & & \\
\hline Pisione remota & 0.15 & & & & \\
\hline Ischyrocerus anguipes & 0.15 & & & & \\
\hline Nicolea venustula & 0.13 & & & & \\
\hline Perioculodes longimanus & 0.13 & & & & \\
\hline Microporella ciliata & 0.11 & & & & \\
\hline Prionospio banyulensis & 0.10 & & & & \\
\hline Pseudopotamilla reniformis & 0.10 & & & & \\
\hline Elminius modestus & 0.10 & & & & \\
\hline Clausinella fasciata & 0.10 & & & & \\
\hline
\end{tabular}

Table 3. Summary of species found to be unique to the Inner Silver Pit $(n=10)$, the Sole Pit $(n=5)$ and the wider study region in the Outer Humber $(n=110)$. Only species with an average abundance greater than 0.1 per grab are shown. The total number of unique taxa is given in brackets. 
A) Coracuta obliquata

\begin{tabular}{ccl}
\hline No.Variables & Correlation & Variables \\
\hline \hline 1 & 0.341 & Geomorphic Feature \\
\hline 2 & 0.307 & Geomorphic Feature, Seafloor Rugosity \\
\hline 1 & 0.230 & Wave Strength \\
\hline 2 & 0.230 & Geomorphic Feature, Wave Strength \\
\hline 1 & 0.230 & Near Bed Temperature \\
\hline
\end{tabular}

\section{B) Sabellaria spinulosa}

\begin{tabular}{ccl}
\hline No.Variables & Correlation & Variables \\
\hline \hline 2 & 0.379 & Sorting, Tidal Current Velocity \\
\hline 3 & 0.363 & Sorting, Wave Strength, Tidal Current Velocity \\
\hline 2 & 0.350 & Sorting, Wave Strength \\
\hline 4 & 0.339 & \% Sand, Sorting, Wave Strength, Tidal Current Velocity \\
\hline 4 & 0.334 & Sorting, Wave Strength, Near Bed Temperature, Tidal Current Velocity \\
\hline
\end{tabular}

Table 4. Summary of Bio-Env analyses carried to investigate the environmental surrogates which best correlate with the distribution patterns of A) Coracuta obliquata and B) Sabellaria spinulosa in the Outer Humber region. 